\title{
To Correlate, RBC Indices in Classifying Spectrum of Aneamia in Adult Females in Tertiory Care Hospital
}

\author{
Dr. Sahiba Kaur ${ }^{*}$, Dr. Pagarao M Pradhan ${ }^{2}$, Dr. C. R Gore ${ }^{3}$
}

${ }^{1}$ Resident, Department of Pathology, Dr. D.Y. Patil Medical College, Sant Tukaram Nagar, Pimpri Colony, Pimpri-Chinchwad, Maharashtra 411018, India

${ }^{2}$ Professor, Department of Pathology, Dr. D.Y. Patil Medical College, Sant Tukaram Nagar, Pimpri Colony, Pimpri-Chinchwad, Maharashtra 411018, India

${ }^{3}$ Professor and Head, Dr. D.Y. Patil Medical College, Sant Tukaram Nagar, Pimpri Colony, Pimpri-Chinchwad, Maharashtra 411018, India

DOI: $10.36348 /$ sjpm.2020.v05i02.015

| Received: 17.02.2020 | Accepted: 25.02.2020 | Published: 29.02.2020

*Corresponding author: Dr. Sahiba Kaur

\section{Abstract}

Aims: To correlate AGE, TYPE, RBC INDICES in deciding the severity of anaemia in adult females in tertiory care hospital. Settings and Designs: A hospital based cross sectional study was done at our tertiary care centre in central clinical laboratory of Dr. D. Y. Patil Medical College \& Hospital and Research Centre, Pimpri, Pune among 1000 adult females to evaluate prevalence of spectrum of anaemia. Considering a confidence level of $95 \%$ and confidence interval of 3.1 the number of patients in our study to achieve statistical significance is 999. This was calculated by Survey System (http://www.surveysystem.com/sscalc.htm\#one). The Survey System ignores the population size when it is "large" or unknown. Population size is only likely to be a factor when you work with a relatively small and known group of people (e.g., the members of an association). Hence a sample size of 1000 was considered adequate for our study. Results: Majority of the females (42.44\%) were in the age group of 26-35 years followed by $31.9 \%$ in the age group of $18-25$ years, $19.2 \%$ in the age group of 36-45 years, $4.9 \%$ in the age group of 46-55 years and 1.6\% in the age group of 56-65 years. $410(41 \%)$ females had mild anaemia while $440(44 \%)$ and $150(15 \%)$ females had moderate and severe anaemia. The mean corpuscular volume $(\mathrm{MCV})$ of females with mild anaemia was $70.94 \pm 1.35 \mathrm{fl}$ while the mean $\mathrm{MCV}$ of females with moderate and severe anaemia was $66.29 \pm 2.43 \mathrm{fl}$ and $60.82 \pm 1.77 \mathrm{fl}$ respectively. There was significant decrease in mean corpuscular volume $(\mathrm{MCV})$ with increase in severity of anaemia as per ANOVA test $(\mathrm{p}<0.05)$. The mean corpuscular haemoglobin $(\mathrm{MCH})$ of females with mild anaemia was $25.74 \pm 2.38 \mathrm{pg}$ while the mean $\mathrm{MCH}$ of females with moderate and severe anaemia was $21.16 \pm 2.07 \mathrm{pg}$ and $17.84 \pm 1.96 \mathrm{pg}$ respectively. There was significant decrease in mean corpuscular haemoglobin $(\mathrm{MCH})$ with increase in severity of anaemia as per ANOVA test $(\mathrm{p}<0.05)$. The mean corpuscular haemoglobin concentration (MCHC) of females with mild anaemia was $32.76 \pm 3.14$ while the mean MCHC of females with moderate and severe anaemia was $29.55 \pm 2.83$ and $26.91 \pm 2.34$ respectively. There was significant decrease in mean corpuscular haemoglobin concentration (MCHC) with increase in severity of anaemia as per ANOVA test $(\mathrm{p}<0.05)$. The mean red cell distribution width (RDW) of females with mild anaemia was $17.72 \pm 0.87 \%$ while the mean RDW of females with moderate and severe anaemia was $18.26 \pm 1.18 \%$ and $20.05 \pm 1.37 \%$ respectively. There was increase in red cell distribution width (RDW) with increase in severity of anaemia but the increase was statistically not significant as per ANOVA test ( $p>0.05)$. Conclusion: Iron deficiency anemia is increasing in females, specially in reproductive age group of developing countries. The haematological parameters can aid in early recognition of type and cause of anaemia and thereby improve the outcome. The study confirms that iron deficiency anaemia is the most common cause of anaemia in pregnancy and is a major health problem in developing and developed countries. Early detection, treatment and prevention of anemia can improve maternal as well as child outcome.

Keywords: Anaemia, MCV, MCH, MCHC, RDW.

Copyright @ 2020: This is an open-access article distributed under the terms of the Creative Commons Attribution license which permits unrestricted use, distribution, and reproduction in any medium for non-commercial use (NonCommercial, or CC-BY-NC) provided the original author and sources are credited.

\section{INTRODUCTION}

Anaemia is a major public health problem. Anaemia, is not a diagnosis in itself but is an objective for presence of disease. It is especially prevalent in women of reproductive age, particularly during pregnancy. Poor nutritional status during pregnancy is associated with inadequate weight gain, anemia, retarded fetal growth low birth weight, still births, preterm delivery, intrauterine growth retardation, morbidity and mortality rates [1]. 
Anemia is defined as a "decrease in whole body red cell mass, a definition that precludes relative decreases in red blood cell count, haemoglobin, or haemocrit, which occur when the plasma volume". In practice, the measurement of red cell mass is not easy and anemia is usually diagnosed based on a reduction in the hematocrit (the ratio of packed red cells to total blood volume) and the hemoglobin concentration of the blood to levels that are below the normal range [2].

A classification of anemia is based on underlying mechanism and according to alterations in red cell morphology. Morphologic characteristics provide etiology clues such as red cell size (normocytic, microcytic, macrocytic), degree of hemoglobinization, reflected in the color of red cells (normochromic or hypochromic) and shape. In general, microcytic hypochromic anemias are caused by disorders of hemoglobin synthesis (most often iron deficiency) while macrocytic anemias often from abnormalities that impair the maturation of erythroid precursors in the bone marrow. Normochromic, normocytic anemias have diverse etiologies; in some of these anemias, specific abnormalities of red cell shape provide an important clue about cause.

\section{MATERIAL AND METHODS}

A hospital based cross sectional study was done at our tertiary care centre in central clinical laboratory of Dr. D. Y. Patil Medical College \& Hospital and Research Centre, Pimpri, Pune among 1000 adult females to evaluate prevalence of spectrum of anaemia.

Study Design: A hospital based prospective observational cross sectional study.

Study Duration: 2.5 years

Data analysis was based on records of the investigations obtained in Central Clinical Laboratory of Dr. D.Y Patil Hospital.

Hospital resources and laboratory data was utilized and no patient/hospital funding was required. An institutional ethics committee clearance (IECC) was obtained before the start of the study.

\section{A waiver in Patient's Informed and Written Consent was Done}

Study Population: 1000 consecutive cases of adult females to evaluate prevalence of spectrum of anaemia who fulfilled the inclusion criteria.

\section{Sample Size: 1000 patients}

Considering a confidence level of $95 \%$ and confidence interval of 3.1 the number of patients in our study to achieve statistical significance is 999. This was $\begin{array}{llll}\text { calculated by } & \text { Survey }\end{array}$ (http://www.surveysystem.com/sscalc.htm\#one). The Survey System ignores the population size when it is "large" or unknown. Population size is only likely to be a factor when you work with a relatively small and known group of people (e.g., the members of an association). Hence a sample size of 1000 was considered adequate for our study.

\section{CRITERIA OF ANAEMIAS}

Adult Non Pregnant Females HB Less Than 12 gm \%.

Adult Pregnant Females HB Less Than 11 gm $\%$

\section{INCLUSION CRITERIA}

- Adult females Age 18 yrs or above.

- Anaemia in non pregnant and pregnant adolescent girls.

\section{EXCLUSION CRITERIA}

- Adult females who are on treatment of anaemia.

- Females less than 18 yrs.

\section{METHODOLOGY}

Institutional ethical committee (iec) clearance was obtained before start of study.The study was carried at ccl of Dr D.Y Patil Medical College, Pune for a period of 2.5yrs $2017-2019$. Total of 1000 cases of adult females that came for ccl were studied. The sample for test were collected in edta tube. The slides were prepared and smears made. The sample were evaluated in the cell counter for various indices. Reports of cell counter and pbs were assessed and types of anaemia were observed and noted. Bone marrow findings of all the patients were unavailable.

\section{OBSERVATIONS AND RESULTS}

A hospital based cross sectional study was done among 1000 adult females to evaluate prevalence of spectrum of anaemia.

\section{DISTRIBUTION OF FEMALES ACCORDING TO} AGE

Majority of the females $(42.44 \%)$ were in the age group of $26-35$ years followed by $31.9 \%$ in the age group of $18-25$ years, $19.2 \%$ in the age group of $36-45$ years, $4.9 \%$ in the age group of $46-55$ years and $1.6 \%$ in the age group of 56-65 year (Table-1 \& Chart-1).

\section{ASSOCIATION OF MEAN CORPUSCULAR VOLUME (MCV) AND SEVERITY OF ANAEMIA OF FEMALES}

The mean corpuscular volume (MCV) of females with mild anaemia was $70.94 \pm 1.35 \mathrm{fl}$ while the mean MCV of females with moderate and severe anaemia was $66.29 \pm 2.43 \mathrm{fl}$ and $60.82 \pm 1.77 \mathrm{fl}$ respectively. There was significant decrease in mean corpuscular volume (MCV) with increase in severity of 
anaemia as per ANOVA test $(\mathrm{p}<0.05)$ (Table-2 \& Chart-2).

\section{ASSOCIATION OF MEAN CORPUSCULAR HAEMOGLOBIN (MCH) AND SEVERITY OF ANAEMIA OF FEMALES}

The mean corpuscular haemoglobin $(\mathrm{MCH})$ of females with mild anaemia was $25.74 \pm 2.38 \mathrm{pg}$ while the mean $\mathrm{MCH}$ of females with moderate and severe anaemia was 21.16 $\pm 2.07 \mathrm{pg}$ and $17.84 \pm 1.96 \mathrm{pg}$ respectively. There was significant decrease in mean corpuscular haemoglobin $(\mathrm{MCH})$ with increase in severity of anaemia as per ANOVA test $(\mathrm{p}<0.05)$.

\section{ASSOCIATION OF MEAN CORPUSCULAR HAEMOGLOBIN CONCENTRATION (MCHC) AND SEVERITY OF ANAEMIA OF FEMALES}

The mean corpuscular haemoglobin concentration (MCHC) of females with mild anaemia was $32.76 \pm 3.14$ while the mean MCHC of females with moderate and severe anaemia was $29.55 \pm 2.83$ and $26.91 \pm 2.34$ respectively. There was significant decrease in mean corpuscular haemoglobin concentration
(MCHC) with increase in severity of anaemia as per ANOVA test $(\mathrm{p}<0.05)$.

\section{ASSOCIATION OF RED CELL DISTRIBUTION WIDTH (RDW) AND SEVERITY OF ANAEMIA OF FEMALES}

The mean red cell distribution width (RDW) of females with mild anaemia was $17.72 \pm 0.87 \%$ while the mean RDW of females with moderate and severe anaemia was $18.26 \pm 1.18 \%$ and $20.05 \pm 1.37 \%$ respectively. There was increase in red cell distribution width (RDW) with increase in severity of anaemia but the increase was statistically not significant as per ANOVA test $(\mathrm{p}>0.05)$.

Table-1: Distribution of Females According To Age

\begin{tabular}{|l|l|l|}
\hline Age (years) & $\mathbf{N}$ & $\mathbf{\%}$ \\
\hline $\mathbf{1 8 - 2 5}$ years & 319 & $31.9 \%$ \\
\hline $\mathbf{2 6 - 3 5}$ years & 424 & $42.4 \%$ \\
\hline $\mathbf{3 6 - 4 5}$ years & 192 & $19.2 \%$ \\
\hline 46-55 years & 49 & $4.9 \%$ \\
\hline$>\mathbf{5 5}$ years & 16 & $1.6 \%$ \\
\hline Total & 1000 & $100 \%$ \\
\hline
\end{tabular}

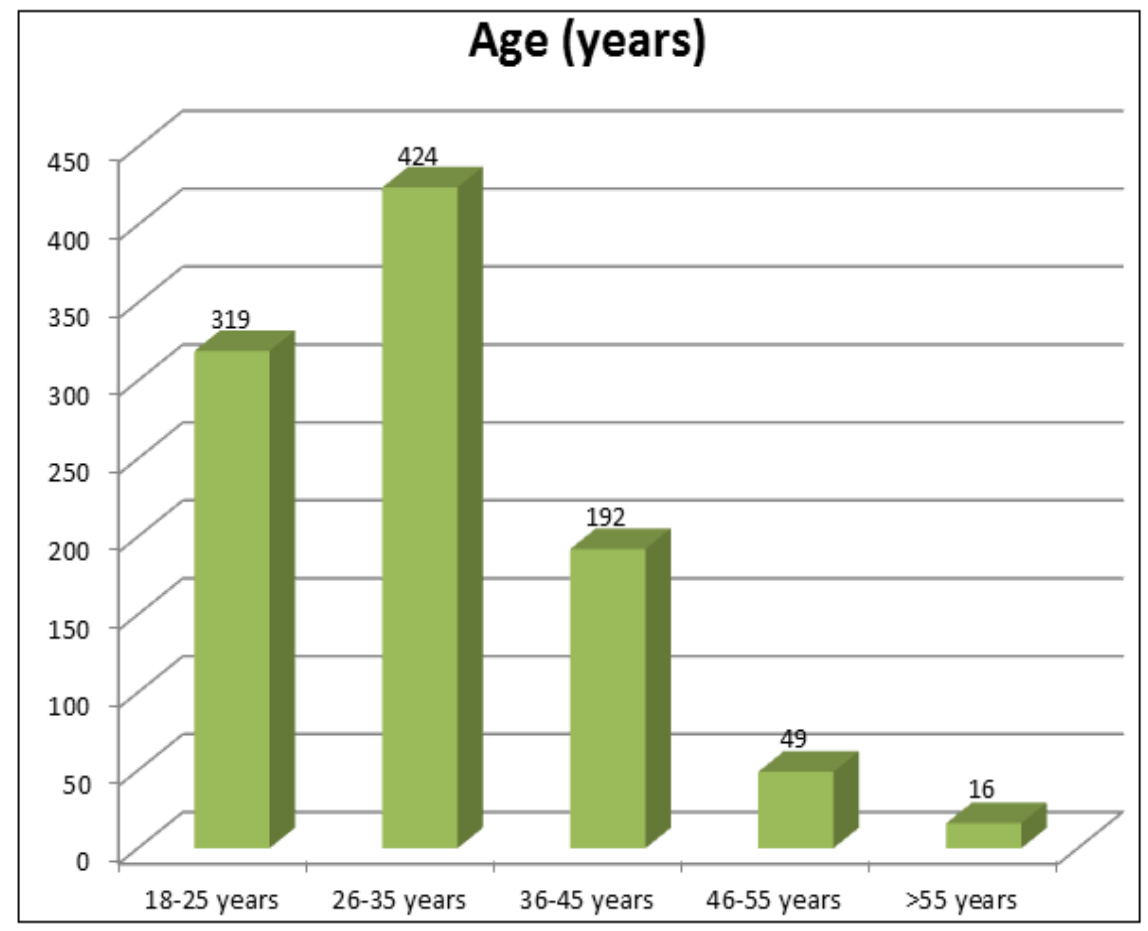

Chart-1: Distribution of females according to Age

Table-2: Association of Mean Corpuscular Volume (MCV) and Severity of Anaemia of females

\begin{tabular}{|l|l|l|l|}
\hline \multirow{2}{*}{ Severity of Anaemia } & \multicolumn{2}{|l|}{ Mean Corpuscular Volume (fl) } & \multirow{2}{*}{ V Value } \\
\cline { 2 - 3 } & Mean & SD & \\
\hline Mild & 70.94 & 1.35 & \multirow{2}{*0.05}{} \\
\hline Moderate & 66.29 & 2.43 & \\
\hline Severe & 60.82 & 1.77 & \\
\hline
\end{tabular}




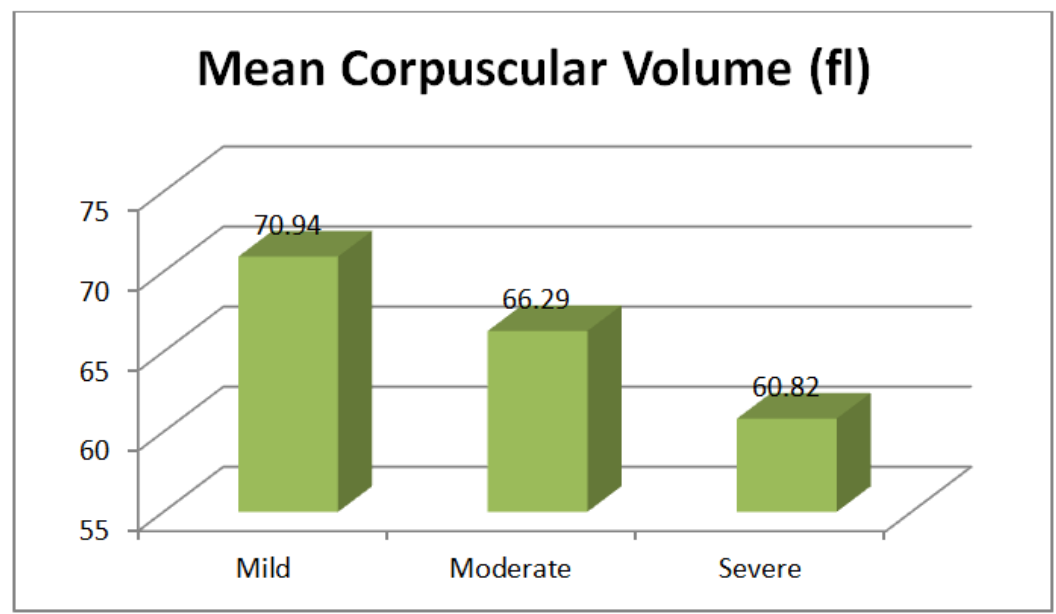

Chart-2: Association of Mean Corpuscular Volume (MCV) and Severity of Anaemia of females

\section{DISCUSSION}

A hospital based cross sectional study was done among 1000 adult females to evaluate prevalence of spectrum of anaemia. In the present study, majority of the females (42.44\%) were in the age group of 26-35 years followed by $31.9 \%$ in the age group of $18-25$ years, $19.2 \%$ in the age group of $36-45$ years, $4.9 \%$ in the age group of $46-55$ years and $1.6 \%$ in the age group of 56-65 years. This is similar to the studies of Kumar MR et al., [2], Sharma AK et al., [6], Sarin J et al., [3] and Trivedi J et al., [4].

Kumar MR et al., [5] assessing the spectrum and characteristics of admitted patients for anaemia found mean age of the patients was 46.92 years (minimum 13 years and maximum 85 years, SD \pm 16.80 years).

Sarin J et al., [3] study determining the prevalence of anemia among antenatal mothers with a view to develop and evaluate a planned health education programme on prevention and management of anemia in pregnancy found $(68 \%)$ were in the age group of 21-25 years, followed by $21 \%$ in the age group of 26-30 years and $10 \%$ of the in the age group of below 20 years.

Trivedi J et al., [4] study assessing the haematological parameters in anemic pregnant women found 70 patients $(58.33 \%)$ to be anaemic i.e. they had haemoglobin concentration less than $11 \mathrm{~g} \%$. $42 \%$ of these were primi gravida. Out of 70 cases of pregnant anaemic women, 7 were less than 20 years of age, 30 women had age between $20-25$ and women in age group 26-30 were $33.58 .33 \%$ were found to be anaemic with hemoglobin less than $11 \mathrm{gm} \%$.

In our study, $410(41 \%)$ females had mild anaemia while $440(44 \%)$ and $150(15 \%)$ females had moderate and severe anaemia. This is comparable to the studies of Kumar MR et al., [5], Sharma AK et al., [6], Bhattacherjee S et al., [8] and Trivedi J et al., [4].
Kumar MR et al., [5] assessing the spectrum and characteristics of admitted patients for anemia found mean hemoglobin was $6.9 \mathrm{gm} \%$ (minimum 2.2, maximum 11.9 and SD 2.34). $47 \%$ patients had severe anemia.

It was observed in the present study that the mean corpuscular volume (MCV) of females with mild anaemia was $70.94 \pm 1.35 \mathrm{fl}$ while the mean $\mathrm{MCV}$ of females with moderate and severe anaemia was $66.29 \pm 2.43 \mathrm{fl}$ and $60.82 \pm 1.77 \mathrm{fl}$ respectively. There was significant decrease in mean corpuscular volume (MCV) with increase in severity of anaemia as per ANOVA test $(\mathrm{p}<0.05)$. Sharma AK et al., [6] and Prasanna MR et al., [7] noted similar observations in their studies.

Sharma AK et al., [6] evaluating the occurrence of Iron deficiency anemia among females of reproductive age group reported mean corpuscular volume (MCV) of females with mild anaemia was 62.1$79.9 \pm 71.9$ while the mean MCV of females with

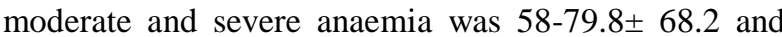
53-66 \pm 60.3 respectively.

Prasanna MR et al., [7] study assessing the prevalence of anemia in adult patients reported high MCV was seen in one case which on peripheral smear showed macrocytosis. Whereas low MCV was seen in 16 patients with microcytic hypochromic, 3 patients had normocytic normochromic, remaining 5 patients showed dimorphic picture.

It was observed in our study that the mean corpuscular haemoglobin $(\mathrm{MCH})$ of females with mild anaemia was $25.74 \pm 2.38 \mathrm{pg}$ while the mean $\mathrm{MCH}$ of females with moderate and severe anaemia was $21.16 \pm 2.07 \mathrm{pg}$ and $17.84 \pm 1.96 \mathrm{pg}$ respectively. There was significant decrease in mean corpuscular haemoglobin $(\mathrm{MCH})$ with increase in severity of anaemia as per ANOVA test $(\mathrm{p}<0.05)$. This finding was consistent with the studies of Prasanna MR et al., [7] and Trivedi J et al., [4]. 
Prasanna MR et al., [7] study assessing the prevalence of anemia in adult patients observed Normal $\mathrm{MCH}$ in predominantly normocytic normochromic anemia and few microcytic anemias. High $\mathrm{MCH}$ was seen in macrocytic and one case of normocytic normochromic anemia. Low $\mathrm{MCH}$ was seen in microcytic hypochromic and some in normocytic normochromic and dimorphic anemia.

Trivedi J et al., [4] study assessing the haematological parameters in anemic pregnant women reported mean value of $\mathrm{MCV}$ was $77.11 \mathrm{fl}$, mean $\mathrm{MCH}$ was $26.62 \mathrm{pg}$, mean MCHC was 32.92 .

In our study, the mean corpuscular haemoglobin concentration (MCHC) of females with mild anaemia was $32.76 \pm 3.14$ while the mean $\mathrm{MCHC}$ of females with moderate and severe anaemia was $29.55 \pm 2.83$ and $26.91 \pm 2.34$ respectively. There was significant decrease in mean corpuscular haemoglobin concentration (MCHC) with increase in severity of anaemia as per ANOVA test $(\mathrm{p}<0.05)$. This is similar to the study of Prasanna MR et al., [7].

Prasanna MR et al., [7] study assessing the prevalence of anemia in adult patients reported normal MCHC in 36 patients. Out of these patients, on peripheral smear examination 31 patients had normocytic normochromic anemia, 3 showed microcytic anemias, 2 showed dimorphic picture. Low MCHC is seen in 15 patients with microcytic anemia, 1 macrocytic and remaining 6 in dimorphic anemia.

In the present study, the mean red cell distribution width (RDW) of females with mild anaemia was $17.72 \pm 0.87 \%$ while the mean RDW of females with moderate and severe anaemia was $18.26 \pm 1.18 \%$ and $20.05 \pm 1.37 \%$ respectively. There was increase in red cell distribution width (RDW) with increase in severity of anaemia but the increase was statistically not significant as per ANOVA test $(\mathrm{p}>0.05)$. This is comparable to the studies of Sharma AK et al., [6] and Trivedi J et al., [4].

Sharma AK et al., [6] evaluating the occurrence of Iron deficiency anemia among females of reproductive age group observed mean corpuscular volume (MCV) was much lower in all cases of patients suffering from mild to severe anaemia. Values of Red cell distribution width (RDW) were found to be in variance than the normal values.

Trivedi J et al., [4] study assessing the haematological parameters in anemic pregnant women reported mean red cell distribution width coefficient of variation (RDW CV) was $15.70+1.92 \%$.
In the present study, there was significant difference in red cell indices [Packed Cell Volume (PCV), Mean Corpuscular Volume (MCV), Mean Corpuscular Haemoglobin (MCH), Mean Corpuscular Haemoglobin Concentration (MCHC), Red Cell Distribution Width (RDW)] as per ANOVA test $(p<0.05)$. Similar observations were noted in the study of Prasanna MR et al., [7].

Prasanna MR et al., [7] study assessing the prevalence of anemia in adult patients reported mean values of $\mathrm{Hb}, \mathrm{HCT}, \mathrm{MCV}, \mathrm{MCH}, \mathrm{MCHC}$ and RDW correlated with the morphological features on peripheral in all the groups except dimorphic anemias. In few cases MCV and $\mathrm{MCH}$ did not correlate with the morphological picture found in the peripheral smear examination. Two cases of microcytic hypochromic anemia had normal $\mathrm{MCV}$ and $\mathrm{MCH}$ and three cases normocytic normochromic anemia had borderline values of $\mathrm{MCV}$ and $\mathrm{MCH}$, which on peripheral smear examination show insignificant number of microcytes

\section{REFERENCES}

1. Kansal, B., Guleria, K., Agarwal, N., \& Sethi, K. (2004). Effect of maternal nutritional supplementation on foetal growth parameters and doppler flow velocity in growth restricted foetuses. Ind J Nutr Dietet, 41, 198-204.

2. Kumar, V., Abbas, A. K., \& Fausto, N. (2010). Robins and Cotran Pathologic Basis of Disease. 8th ed. Ch. 14. Philadelphia, PA: Saunders Elsevier, 644.

3. Uptmore, C., Connell, B., \& Hart, D. (2001). Comparison of the Sysmex XE-2100 to the Abbott Cell-Dyn 4000, automated hematology analyzer. Sysmex Journal International, 11, 22-26.

4. Rajesh, K. M., Ramesh, B. P., \& Ilahi, M. (2013). Iron deficiency anemia: an experience with one hundred consecutive hospitalized patients. Medical Science, 2(1).

5. Sivapriya, S., \& Laxmipriya, P. (2017). A study to assess the knowledge and practices regarding prevention of anaemia among antenatal women attending a tertiary level hospital in Pune. International Journal of Scientific Research, 69(10).

6. Sharma, A. K., Bansal, A., Sharma, S., \& Sujatha, R. (2017). Study on diagnostic parameters in women of reproductive age group suffering from iron deficiency anaemia. Indian Journal of Scientific Research, 7(2), 83-89.

7. Prasanna, M., Ha, H. Y., Cho, E., Hong, S. A., \& Oh, I. H. (2004). Influence of cathode gas diffusion media on the performance of the PEMFCs. Journal of Power Sources, 131(1-2), 147-154. 